http://dx.doi.org/10.12775/szhf.2014.048

Tomasz Kubalica

\title{
Johannes Volkelt i Mścisław Wartenberg - neokantowska filozofia Kanta w Polsce
}

Choć neokantyzm miał na celu odczytanie ducha filozofii Kanta, a nie jej litery, to jednak poszczególne stanowiska neokantowskie wyrastają z nauki zawartej w Kantowskich Krytykach, która służyła im za źródło inspiracji dla samodzielnego i oryginalnego filozofowania. Ta dwojaka postawa neokantystów wobec filozofii Kanta przyniosła jednak, obok nowych idei, również głęboką potrzebę pogłębiania znajomości doktryny samego Kanta. To oznacza, że niezwykle trudno byłoby oderwać filozofię Kanta od filozofii jego duchowych spadkobierców.

Przedmiot niniejszego tekstu sytuuje się pomiędzy problematyką recepcji myśli kantowskiej w Polsce a zagadnieniem historii polskich badań nad tą filozofią, gdyż dotyczy wpływu szeroko pojętego ruchu neokantowskiego na przyswojenie idei Kanta nad Wisłą ${ }^{1}$. W tym artykule pragnę porównać koncepcje filozoficzne dwóch myślicieli w różny sposób związanych z Polską:

\footnotetext{
* Projekt został sfinansowany ze środków Narodowego Centrum Nauki, przyznanych na podstawie decyzji numer DEC-2011/03/B/HS1/00373.

${ }^{1}$ Jednoznaczne określenie przynależności narodowej poglądów omawianych w artykule filozofów nie jest możliwe, gdyż przedstawiona w nim myśl filozoficzna - tak jak filozofia jako taka - jest ponadnarodowa i przekracza granice państwowe, etniczne oraz polityczne. Dowodzi tego międzynarodowa biografia omawianych myślicieli, która łączy wątki nie tylko polskie, niemieckie, austriackie, lecz także szwajcarskie i ukraińskie. $\mathrm{Z}$ tego powodu użyte zostało pozbawione znaczenia etniczno-politycznego - pojęcie "filozofia w Polsce«, które ma sens wyłącznie biograficzny i geograficzny.
} 
profesora filozofii Uniwersytetu Lwowskiego Mścisława Wartenberga (1868-1938) oraz pochodzącego z Lipnika (obecnie część Bielska-Białej), profesora uniwersytetów w Bazylei, w Würzburgu i w Lipsku, Johannesa Volkelta (1848-1930), który od czasów swoich studiów był ponadto mocno związany z Wiedniem. Pod względem filozoficznym łączą ich badania nad myślą Kanta oraz obrona naukowego charakteru metafizyki. Celem tego porównania jest rozpoznanie granicy pomiędzy literalnym odczytaniem filozofii Kanta a jej duchem wyrażonym w nowy sposób przez neokantystów. Rozpoczniemy od stanowiska Volkelta, który jest ważną postacią, zarówno jako badacz myśli Kanta, jak i obrońca możliwości uprawiania metafizyki jako nauki, by w dalszej kolejności przejść do omówienia podobieństw oraz różnic w poglądach Wartenberga.

\section{Neokantyzm Volkelta}

Krótko wzmiankowanym przez Marka Kazimierczaka obok Rudolfa H. Lotzego, Eduarda von Hartmanna i Wilhelma Wundta zwolennikiem metafizyki indukcyjnej - a przede wszystkim metafizyki krytycznej - był Johannes Volkelt ${ }^{2}$, którego poglądy - obok Ottona Liebmanna - mogą również stanowić punkt odniesienia dla stanowiska Wartenberga, gdyż charakteryzuje go z jednej strony neokantowskie odniesienie do filozofii Kanta, a z drugiej pozytywny stosunek do metafizyki.

\subsection{Volkelt jako badacz Kanta}

Podobnie jak później Wartenberg, Volkelt rozpoczyna swoją karierę naukową od rozprawy doktorskiej poświęconej myśli Kanta. Praca nosi tytuł Immanuel Kants Erkenntnistheorie, ukazuje się w 1879 roku i podejmuje rozważania nad problemem sceptycyzmu w filozofii Kanta. Celem Volkelta jest „próba analizy Kantowskiej teorii poznania, która odda przy tym sprawiedliwość wszystkim stronom jego teoriopoznawczego myślenia i odsłoni jego najbardziej fundamentalne motywy w ich wzajemnie zazębiającej się współ-

\footnotetext{
${ }^{2}$ Por. M. Kazimierczak, W poszukiwaniu naukowego charakteru metafizyki. Z dziejów recepcji niemieckiej filozofii pokantowskiej w Polsce, Poznań 1998, s. 73 i nast.; zob. też. A. J. Noras, Historia neokantyzmu, Katowice 2012, s. 271 i nast.
} 
pracy $^{3}$. Chodzi zatem o taką analizę podstawowych założeń filozofii Kanta, która - jak przystało na badanie neokantysty - chce zrozumieć myśl autora Krytyki czystego rozumu lepiej niż on sam siebie rozumiał, czyli wraz z ujawnieniem podstawowych sprzeczności zawartych w jego poglądach ${ }^{4}$. Charakterystyczny jest tutaj również nowożytny motyw „nowego początku”, który łączy myślenie Volkelta z Kartezjuszem i Edmundem Husserlem. Tak jak oni, Volkelt uważa, że wszelkie filozofowanie należy rozpocząć od analizy teoriopoznawczych podstaw wiedzy, czemu służyć ma metodyczny sceptycyzm.

Volkelt łączy sceptycyzm z pozytywistycznym pryncypium, które ogranicza poznanie do sfery indywidualnych przedstawień: „Nasze przedstawienia są tym jedynym, czego bezpośrednio doświadczamy, dlatego wiedzy o nich nie może nam zabrać nawet najbardziej radykalne wątpienie"s. Pozytywistyczne ograniczenie do sfery przedstawień prowadzi Volkelta do odrzucenia naiwnej, realistycznej i zdroworozsądkowej - opartej na teorii odbicia - teorii poznania: „Na samym początku filozofowania nie mamy żadnego środka, by rozstrzygnąć, czy treść naszej naoczności w jakimś stopniu odbija istniejący na zewnątrz świat. Wręcz trzeba najpierw przyjąć możliwość, że ta nasza na-

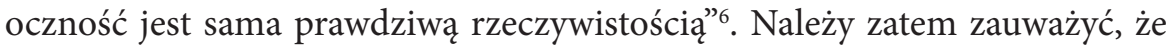
Volkelt - inaczej niż Wartenberg ${ }^{7}$ - zdecydowanie odrzuca teorię odbicia, gdyż przyjmuje, że w sferze przedstawień nie mamy żadnego uprzywilejowanego wglądu w odzwierciedlaną przez nasze przedstawienia rzeczywistość, co odpowiada Kantowskiemu przekonaniu o niepoznawalności rzeczy samej w sobie.

W tym kontekście warto nadmienić, że pryncypium pozytywistyczne nie oznacza dla Volkelta pochwały pozytywizmu. Jak podaje Thomas Neumann: „Faktyczny punkt styczności między »filozofią czystego doświadczenia« [...] a Volkelta "pozytywistycznym « pryncypium poznania przedlogicznej pewności istnieje do tego momentu, gdy oba powołują się na (rzekomo) nietknięty przez myśl (i oczywiście przez język) opis faktów, bez uwzględnienia tego,

${ }^{3}$ J. Volkelt, Immanuel Kant's Erkenntnistheorie: nach ihren Grundprincipien analysirt: ein Beitrag zur Grundlegung der Erkenntnistheorie, Leipzig 1879, s. III.

${ }^{4}$ Tamże, s. IV-V.

${ }^{5}$ Tamże, s. 1; por. O. Hallesby, Johannes Volkelts Erkenntnistheorie. Eine Darstellung und Kritik, Dissertation, Erlangen 1909, s. 35 i nast.; T. Kubalica, Problem pewności w neokantyzmie Johannesa Volkelta, „Folia philosophica“ 2013, t. 31, s. 136 i nast. Drugie pryncypium poznawcze ma charakter racjonalistyczny.

${ }^{6} \mathrm{~J}$. Volkelt, Immanuel Kant's Erkenntnistheorie, wyd. cyt., s. 2.

${ }^{7}$ Por. M. Kazimierczak, W poszukiwaniu, wyd. cyt., s. 82. 
że nie tylko językowe "wypowiedzi« o faktach potrzebują myślnego określenia, ale również same fakty nie interpretują się jako fakty"8. Volkelt nie poprzestaje zatem na pozytywistycznym pryncypium i podejmuje zagadnienie poznania transsubiektywnego ${ }^{9}$. Zakłada przy tym absolutną pewność bezpośrednio doświadczanego przeżycia i pragnie wykazać sposób transsubiektywnego wyjścia poza bezpośrednie przeżycie ${ }^{10}$. Dlatego ujęcie Volkelta nie jest ani pozytywistyczne, ani sceptyczne, lecz krytyczne, gdyż jego punktem wyjścia jest absolutny podział sfery poznania na bezwzględnie pewne bezpośrednie przeżycia oraz pozbawioną pewności transsubiektywną sferę przedmiotową. Krytyczne podejście $\mathrm{w}$ teorii poznania musi zatem przedstawić swoje metafizyczne założenia.

Z krytycznego podejścia mogą wynikać dwie formy filozofii krytycznej ${ }^{11}$ : można albo przyznać, że transsubiektywnemu przedmiotowi przysługuje niepełny i względny stopień pewności, albo popaść w absolutny sceptycyzm i ogłosić „absolutną niepewność wszystkiego tego, co znajduje się poza naszymi przedstawieniami”' ${ }^{12}$. Jeżeli tak jak w pierwszej formie filozofii krytycznej wkraczamy w dziedzinę tego, co transsubiektywne, to tworzymy metafizykę. W absolutnym sceptycyzmie natomiast odrzucamy możliwość uzyskania wiedzy pewnej o tym, co pozapodmiotowe. Jak dotąd jednak nie było $\mathrm{w}$ filozofii konsekwentnego przedstawiciela tak rozumianego skrajnego sceptycyzmu ${ }^{13}$. Tak pojmowana kwestia absolutnego sceptycyzmu zostaje odniesiona do Kantowskiego stanowiska wobec poznawalności rzeczy samej w sobie, w którym Volkelt odkrywa narastające szczególne i skomplikowane problemy - ich przyczyną jest to, że punktem wyjścia dla Kanta nie jest pryncypium pozytywistyczne ${ }^{14}$. Kant nie podjął się odpowiedzi na pytanie o granice między przedstawianiem a tym, co transsubiektywne. Kant nie jest konsekwentny w swym ujęciu niepoznawalności rzeczy samej w sobie, zarówno w zewnętrznej, jak i w wewnętrznej naoczności, gdyż przypisuje im

${ }^{8}$ T. Neumann, Gewissheit und Skepsis. Untersuchungen zur Philosophie Johannes Volkelts, Amsterdam 1978, s. 87.

${ }^{9}$ Por. J. Volkelt, Immanuel Kant's Erkenntnistheorie, wyd. cyt., s. 2-3.

${ }^{10}$ Por. O. Hallesby, Johannes Volkelts Erkenntnistheorie, wyd. cyt., s. 14 i nast.; por. także

T. Kubalica, Problem pewności, wyd. cyt., s. 148 i nast.

${ }^{11}$ Por. J. Volkelt, Immanuel Kant's Erkenntnistheorie, wyd. cyt., s. 8 i nast.

12 Tamże.

${ }^{13}$ Por. tamże, s. 9.

${ }^{14}$ Tamże, s. 11. 
cały szereg negatywnych lub pozytywnych określeń ${ }^{15}$. I tak obok sceptycznego wątpienia w ich poznawalność da się znaleźć w filozofii Kanta zaprzeczające temu racjonalistyczne założenia o ich wielkości, substancjalności, realności, przyczynowości i tak dalej. Volkelt pisze, że „Kant zarazem zaciera i gmatwa tę teoriopoznawczą różnicę podstawową między przedstawianiem a rzeczą samą w sobie, gdy ją wprowadza i traktuje jako nieprzezwyciężalną" ${ }^{16}$. Ta niekonsekwencja ujawnia się w szczególności w rozważaniach nad czwartym paralogizmem, gdzie można znaleźć stwierdzenie w duchu naiwnego realizmu: „Wszelkie spostrzeżenie zewnętrzne dowodzi więc bezpośrednio czegoś rzeczywistego w przestrzeni albo raczej samo jest tym czymś rzeczywistym. Realizm empiryczny jest więc o tyle niewątpliwy, że naszym oglądom zewnętrznym odpowiada coś rzeczywistego w przestrzeni”" ${ }^{17}$.

Volkelt podejmuje również rozważania związane z wewnętrzną koniecznością metafizyki w ujęciu Kanta i wiąże ją z pojęciem myślnej konieczności (Denknothwendigkeit), która jako pryncypium racjonalistyczne umożliwia wyjście poza wyznaczoną przez pozytywistyczne pryncypium sferę przedstawiania i jednocześnie stanowi środek teoretycznego przezwyciężenia absolutnego sceptycyzmu. Volkelt ujmuje znaczenie racjonalistycznego pryncypium myślnej konieczności w następujący sposób:

W myślnej konieczności staje się nam bezpośrednio wiadomym, że w niej wyraża się coś więcej niż tylko subiektywny przymus, że w niej zarazem zostaje rozstrzygnięte coś o transsubiektywnej rzeczywistości. Myślowo konieczna treść przedstawienia narzuca się nam z bezpośrednio wyjaśniającą oczywistością jako odbicie odpowiadającetemu, co transsubiektywne powiązania. W myślnej konieczności bezpośrednio uwewnętrzniamy, że jej treść jest zgodna z treścią odpowiedniej transsubiektywnej rzeczywistości ${ }^{18}$.

W ten sposób myślna konieczność pozwala na odniesienie podmiotu do transsubiektywnej rzeczywistości. Wraz z pojęciem myślnej konieczności Volkelt powraca do odrzuconego wcześniej odbiciowego ujęcia poznania, ponieważ pozapodmiotowe stosunki mają zostać odzwierciedlone jako bez-

\footnotetext{
15 Tamże, s. 13-14.

16 Tamże, s. 21.

${ }^{17}$ I. Kant, Krytyka czystego rozumu, przeł. M. Żelazny, [w:] I. Kant, Dzieła zebrane, t. 2, red. M. A. Chojnacka, M. Marciniak, Toruń 2013, s. 416 (A 375).

${ }^{18}$ J. Volkelt, Immanuel Kant's Erkenntnistheorie, wyd. cyt., s. 24; por. T. Kubalica, Problem pewności, wyd. cyt., s. 144 i nast.
} 
pośrednio narzucająca się oczywistość, a poznanie staje się myślowo koniecznym odbiciem rzeczywistości. W ścisłym związku z przyjęciem przez Volkelta racjonalistycznego pryncypium myślnej konieczności pojawia się jednak bardzo istotna kwestia: czy myślnej konieczności w poznaniu towarzyszy konieczność bytowa istnienia rzeczy poznawanych. Volkelt krytycznie ocenia negatywną odpowiedź Kanta na tak postawione pytanie, stwierdzając, że Kant w ten sposób osłabił pojęcie myślnej konieczności, co doprowadziło do „oburzającej degradacji myślenia filozoficznego” ${ }^{19}$. Istotne jest jednak dalsze pytanie: czy Kantowskie ujęcie problemu w duchu absolutnego sceptycyzmu jest nieuniknione. Powołuje się przy tym na list Kanta do Marcusa Herza z 21 lutego 1772 roku, w którym rozważany jest stosunek pobudzania zachodzący między przedstawieniem i przedmiotem ${ }^{20}$. Kant dochodzi do wniosku, że niezależnie od tego, czy pobudzanie pochodzi od przedstawienia czy od przedmiotu, podmiot pozostaje w obrębie własnych przedstawień. Problem transsubiektywności nie zostaje zatem rozwiązany.

Dystans Volkelta do myśli Kanta okazuje się jednak jeszcze głębszy i dotyczy przede wszystkim metody filozofowania. Najistotniejsze jest to, że zastosowana przez Volkelta argumentacja sceptyczna wiąże się z odrzuceniem "Założenia transcendentalnego"21. Inaczej niż reprezentanci szkół neokantowskich Volkelt nie przywiązuje wagi do metody transcendentalnej Kanta ${ }^{22}$ i ujmuje jego poglądy w duchu Kartezjańskiego fundacjonizmu. Volkelt uznał bowiem transcendentalną teorię poznania za mylną z powodu błędu kolistości $^{23}$. Uważa, że celem teorii poznania jest jego wyjaśnienie „przed wszelkim rzeczywistym poznawaniem” poprzez „ostateczne i najbardziej prymitywne pryncypia poznawania [...], to znaczy takie pryncypia, które już więcej nie opierają się na założeniu poznawania i nie dają się dlatego dalej rozłożyć, zredukować i uzasadnić" ${ }^{24}$. Drogą do ostatecznego ugruntowania podstaw poznania jest Kartezjańskie wątpienie. Odrzucając neokantowski transcendentalizm, paradoksalnie potwierdza forsowany przez neokantystów prymat

\footnotetext{
${ }^{19}$ Tamże, s. 27.

${ }^{20}$ Por. tamże, s. 31.

${ }^{21}$ T. Neumann, Gewissheit und Skepsis, wyd. cyt., s. 12.

${ }^{22}$ Por. A. J. Noras, Kant a neokantyzm badeński i marburski, Katowice 2000, s. 99 i nast.

${ }^{23}$ Por. T. Neumann, Gewissheit und Skepsis, wyd. cyt., s. 26.

${ }^{24}$ J. Volkelt, Die Aufgabe und die Fundamentalschwierigkeit der Erkenntnistheorie als einer voraussetzungslosen Wissenschaft, „Philosophische Monatshefte” 1881, t. 17, s. 518.
} 
teorii poznania w filozofii: „Teoria poznania jest podstawową nauką filozofii, a nawet podstawą całego naukowego poznania w ogóle"25.

Odrzuceniu metody transcendentalnej towarzyszy u Volkelta postulat bezzałożeniowości teorii poznania. Bezzałożeniowość zbliża myśl Volkelta do fenomenologii Husserla, który jak wiadomo, domagał się zawieszenia wszelkich wynikających z naturalnego nastawienia domysłów, teorii oraz spekulacji. U podstaw filozofii Volkelta i Husserla znajduje się przekonanie, że poza zakładaną przez nas warstwą kulturową naszego oglądu świata istnieje świat bezpośrednich przejawów, którego bezpośrednie poznanie jest możliwe na drodze redukcji (epoché), czyli zawieszenia wszelkich dotychczasowych przekonań dotyczących świata i człowieka. Okazuje się, że fenomenologia Husserla jest filozofią opartą na - postulowanym przez Volkelta - pryncypium sceptycznym. Wiele lat przed Husserlem Volkelt zakłada coś na kształt redukcji, która miałaby polegać na wyizolowaniu wszystkiego tego, co w rzeczywistości nie zachodzi w świadomości, między innymi przypuszczeń o istniejących poza świadomością rzeczach. Celem tego zabiegu jest uzyskanie wglądu w same procesy świadomości.

\subsection{Volkelt a problem metafizyki}

Chociaż Volkelt uznaje prymat teorii poznania, to nie wyklucza jednak możliwości metafizyki. Swoje pozytywne stanowisko wobec niej przedstawił w mowie inauguracyjnej z 23 października 1883 roku wygłoszonej w Bazylei ${ }^{26}$, w której nawiązując właśnie do rozważań Kanta, ujął kwestię metafizyki następująco:

Odpowiedź, którą Kant ustalił, brzmi, jak wiadomo, dla metafizyki niezbyt pocieszająco. Wprawdzie uznaje on potrzebę metafizyki za niemożliwą do wykorzenienia, ale samo jej naukowe zaspokojenie zwalcza jako polegające na pozorze i złudzeniu. $Z$ mocą swego ducha i prawdziwą żądzą zniszczenia podkopuje naukowy gmach metafizyki aż do popadnięcia na naszych oczach w kuglarstwo rozumu. Jednak pozwolił on późnej wypłynąć na podstawie postulatów

\footnotetext{
${ }^{25}$ J. Volkelt, Vorträge zur Einführung in die Philosophie der Gegenwart, München 1892, s. 46.

${ }^{26}$ J. Volkelt, Über die Möglichkeit der Metaphysik: Antrittsrede gehalten zu Basel am 23. Oktober 1883, Hamburg 1884. Podobnie jak w przypadku Wartenberga istotny jest tutaj również wpływ Liebmanna. Por. T. Kubalica, Metafizyka krytyczna Otto Liebmanna, „Folia Philosophica" 2014, t. 31.
} 
moralnych pewnemu rodzajowi metafizyki, i to nawet o całkiem pozytywnej naturze ${ }^{27}$.

Volkelt zauważa, że Kant paradoksalnie kwestionuje metafizykę w starym stylu, ale jednocześnie przedstawia założenia nowej metafizyki praktycznej. W tym sensie Kant jest dla Volkelta reformatorem metafizyki, który zmienił znaczenie i sposób uprawiania metafizyki.

Volkelt w pracy Erfahrung und Denken z 1886 roku definiuje metafizykę w następujący sposób: „w najszerszym sensie przez metafizykę rozumie się naukę, której przedmiotem pytania oraz badań jest istota rzeczywistości”28. Oznacza to, że metafizyki nie można wiązać tylko z najgłębszymi problemami absolutu oraz rozważaniami nad tym, co niedostępne zmysłom i doświadczeniu, lecz również ze wszystkimi innymi przedmiotami, które są w kręgu zainteresowania badań nauk przyrodniczych i psychologii. Metafizyka zajmuje się zatem badaniem istoty czasu i przestrzeni, materii, siły i ruchu, a także substancji, przyczynowości i prawa natury oraz świadomości i nieświadomości. Volkelt określa zatem bardzo szeroko przedmiot metafizyki.

Dla niego metafizyka stanowi teorię najogólniejszych i ostatecznych pryncypiów rzeczywistości, która ma wykazać inteligibilne podstawy świata zjawiskowego ${ }^{29}$. Pozostałe nauki, takie jak matematyka, nauki przyrodnicze czy historia, dokonują jedynie powierzchownego i cząstkowego ujęcia otaczającej nas rzeczywistości. Tylko metafizyka może pozwolić na holistyczne, pierwotne i duchowe spojrzenie na rzeczywistość. Najistotniejsza jest zatem nie treść, lecz metoda badań metafizycznych.

Tak jak Wartenberg, Volkelt podkreśla w duchu metafizyki indukcyjnej teoretyczną i praktyczną rolę metafizyki. Negacja naukowego statusu metafizyki prowadzi do zaprzeczenia jej znaczenia dla woli człowieka i ludzkich dążeń. Ważne jest zapewnienie jej statusu nauki, choćby tylko hipotetycznej, gdyż może jej to zagwarantować - nawet mimo braku jednomyślności - znaczenie dla ludzkiego życia. W tym kontekście pojawia się problem ostatecznej rozstrzygalności pytań metafizycznych, które mogą jako takie być niemożliwe do rozwiązania ${ }^{30}$. Nie można jednak zrezygnować z metafizyki, gdyż w kon-

\footnotetext{
${ }^{27}$ Tamże, s. 3-4. Por. T. Kubalica, Johannes Volkelt a problem metafizyki, „Estetyka i Krytyka” 2012, t. 26, s. 16.

${ }^{28}$ J. Volkelt, Erfahrung und Denken. Kritische Grundlegung der Erkenntnistheorie, Hildesheim 2002, s. 433; por. także A. J. Noras, Historia neokantyzmu, wyd. cyt., s. 76.

${ }^{29}$ Por. J. Volkelt, Über die Möglichkeit der Metaphysik, wyd. cyt., s. 5.

${ }^{30}$ Por. tamże, s. 7.
} 
sekwencji metafizycznego sceptycyzmu pozostawałaby jedynie religijna droga poszukiwania odpowiedzi na pytania o życie i świat. Metafizyczny sceptycyzm musiałby jednak charakteryzować również życie duchowe człowieka religijnego i to rodzi wątpliwości Volkelta, który stwierdza, że „metafizycznie niewierzący nie byłby w stanie wypełnić swej religijnej pustki przez religijną pewność"31. Konsekwencją metafizycznego sceptycyzmu jest ateizm. Kwestia możliwości metafizyki ma zatem znaczenie nie tylko czysto naukowe, lecz jak się okazuje, przede wszystkim moralne. Problemy teoretyczne mają istotne skutki dla praktyki.

Jeszcze raz okazuje się, że w metafizyce krytycznej nie treść, lecz metoda jest najistotniejsza. Volkelt uważa, że z punktu widzenia historii metafizyki zasadnicza dyskusja nie dotyczy stanowisk filozoficznych, takich jak spirytualizm i materializm czy teizm, panteizm i ateizm, czy nawet dualizmu i monizmu, lecz problemu, czy rozważania nad najogólniejszymi i ostatecznymi pytaniami o byt (Daseinsfragen) są w ogóle możliwe. W tym najważniejszym sporze Volkelt zauważa trzy następujące sposoby rozwiązania problemu możliwości metafizyki: dogmatyzm, sceptycyzm i krytycyzm.

Pierwszy odnosi się do dogmatycznej metafizyki spekulatywnej, która opiera się na naiwnym przekonaniu, że ma taki sam status naukowy jak matematyka ${ }^{32}$. To przekonanie - jako bezpodstawne - krytykują zarówno neokantyści, jak i pozytywiści, którzy różnią się jednak pod względem przyjętych założeń: neokantyści, w przeciwieństwie do pozytywistów, zakładają istnienie „wielkiego nieznanego (ein grosses Unbekanntes), które panuje poza lub ponad światem doświadczanym"33. To drugie podejście do problemu metafizyki zasługuje na określenie mianem metafizycznego sceptycyzmu. Istnieje jednak trzecia droga pośrednia pomiędzy skrajnością dogmatycznej metafizyki i antymetafizycznego pozytywizmu. Podążają nią metafizycy, którzy „uprawiają swoją naukę na podstawie czy też w sensie krytycznej teorii poznania”" ${ }^{34}$. Jest to również podejście inspirowane myślą autora Krytyki czystego rozumu. Tak uprawiana metafizyka nie rości sobie pretensji do wiedzy absolutnej, lecz opiera się na ograniczonym, zawodnym i niepewnym „opracowującym do-

\footnotetext{
${ }^{31}$ Tamże. Por. także J. Volkelt, Die Gefühlsgewissheit. Eine erkenntnistheoretische Untersuchung, München 1922, s. 77 i nast. (polski przekład fragmentów: J. Volkelt, Pewność uczuciowa. Wybór tekstów, przeł. B. Markiewicz. Warszawa 1983).

${ }^{32}$ Por. J. Volkelt, Über die Möglichkeit der Metaphysik, wyd. cyt., s. 10.

${ }^{33}$ Tamże, s. 11. W tym kontekście można postawić pytanie, czy filozofia Volkelta spełnia to kryterium i tym samym przynależy do neokantyzmu?

${ }^{34}$ Tamże, s. 11.
} 
świadczenie myśleniu”. Przykłady takiego myślenia Volkelt znajduje u Christopha Sigwarta, Ottona Liebmanna, Maxa Wundta, Rudolpha Hermanna Lotzego i Eduarda von Hartmanna. Podane przykłady świadczą o doniosłości problemu metafizyki we współczesnej filozofii.

Volkelt opowiada się po stronie tego trzeciego rodzaju metafizyki krytycznej - metafizyk musi zachować w niej dystans do własnych rozwiązań, które są najczęściej jedynie symboliczne i analogiczne. Moc dowodowa twierdzeń metafizycznych wcale nie musi być dla każdego oczywista. Volkelt uważa, że

przede wszystkim metafizyk musi sobie wyjaśnić, że myślenie indywidualne, gdy tylko chodzi o głębsze pytania o pryncypia, nigdy i nigdzie nie wyrazi absolutnej konieczności myślenia ani idealnej i wiecznej logiki, a konieczność myślenia, jaka panuje w ludzkiej głowie, jest zawsze tylko względnie uprawniona i względnie słuszna, tak że się w różnych głowach urzeczywistnia raz jedna, raz druga strona absolutnej i idealnej konieczności myślenia ${ }^{35}$.

To oznacza, że hipotetyczne rozważania, które są przekonywające dla jednego, mogą nie być przekonywające dla innego.

Podobnie jak Wartenberg, Volkelt zajmuje stanowisko realistyczne i uważa, że przy logicznym rozważaniu bytu musimy mieć do czynienia z samą rzeczywistością:

Gdy ktoś na serio dyskutuje materialistyczną lub jakąś inną idealistyczną hipotezę, to ma przy tym [...] pewność, iż nie działa na ślepo i bezpodstawnie, lecz że w swej obronie trafia w rzecz, mówi coś dotyczącego rzeczywistości. Ta pewność powszechnie wiąże się nieodparcie z logiczną lub myślowo konieczną metodą również w dziedzinie metafizycznej ${ }^{36}$.

Myślowej konieczności musi towarzyszyć zatem z logiczną pewnością konieczność rzeczowa i tylko na jej podstawie można budować metafizykę.

Wielość poglądów na te same problemy metafizyczne świadczy o tym, że metafizyka nie jest doskonała. Dlatego nie można jej twierdzeniom przyznawać statusu absolutnie pewnych, ścisłych, lecz jedynie względnych i przybliżonych. Pod tym względem nie da się jej określić mianem nauki ścisłej, lecz nie musi to skutkować wykluczeniem poza margines naukowości, gdyż wiele nauk nie spełnia wymogu wąsko rozumianej ścisłości. Uprawnienie metafi-

\footnotetext{
35 Tamże, s. 13.

36 Tamże, s. 34.
} 
zyki może polegać również „na ostrożnym, klaryfikującym zastosowaniu logiki do faktów doświadczenia i zakłada ona rozważny sprawdzian uprawnień i zdolności dowodowej poznania i dlatego może w tym sensie rościć prawo do waloru ścisłości i nadzwyczajnej krytyczności" ${ }^{37}$. Okazuje się zatem, że odrzucenie metafizyki dogmatycznej nie neguje możliwości uprawiania metafizyki zgodnie z naukowymi standardami, gdyż nauka jest obecna wszędzie tam, gdzie możliwe są badania oparte na doświadczeniu i logice: „decydującą cechą naukowości jest logiczne opracowanie doświadczenia i ta cecha dotyczy tak samo metafizyki, jak wszystkich pozostałych nauk" ${ }^{38}$. Naprawdę nie istnieje nauka, która zaspokajałaby całkowicie wymóg ścisłości, wystarczy bowiem, że dąży do jego realizowania w odniesieniu skromnego, ale pewnego wyniku.

Postęp metafizyki nie musi być rozumiany jako dostarczanie nowych odkryć, lecz wystarczy, że będzie prowadził do ciągłego wzbogacania, wyostrzania i pogłębienia naszego myślenia ${ }^{39}$. Konkretne poglądy metafizyczne nie są dane raz na zawsze, jak pisze Volkelt: „kto zatem chce wykryć postępy metafizyki, musi zwrócić swą uwagę na ścisłą ciągłość w niepowstrzymanej zmianie metafizycznych punktów widzenia; jeżeli jego wzrok nie jest zbytnio osłabiony przez sceptycyzm, to ujrzy on w tej ciągłości bez większego trudu postępujące zbliżanie się do prawdy, choć owe zbliżanie się może pozostawać ciągle odległe od celu"40. Nie można stawiać problemu możliwości metafizyki w postaci alternatywy: albo postępowa nauka ścisła, albo żadna ${ }^{41}$. Takie podejście wynika z grzechu arogancji i pychy, które nie podejmują próby wielostronnego spojrzenia na kwestie metafizyki i świadczą o niedojrzałości. Dojrzałe podejście wymaga dostrzeżenia trzeciej możliwości, jaką daje metafizyka krytyczna podejmująca wyzwanie empirycznego i logicznego rozważenia konkretnych problemów metafizycznych ${ }^{42}$.

Owa metafizyka krytyczna ma koncentrować się na nieempirycznych składnikach doświadczenia zawartych w każdym nawet najprostszym akcie myślenia i sądzenia. $Z$ doświadczenia bezpośrednio pochodzą wrażenia i spostrzeżenia, a pośrednio - przedstawienia z pamięci, pojęcia, wytwory

\footnotetext{
37 Tamże, s. 15.

38 Tamże, s. 17.

39 Tamże.

40 Tamże, s. 19.

${ }^{41}$ Por. tamże, s. 19.

${ }^{42}$ Por. tamże, s. 20-21.
} 
fantazji oraz uczucia i zamiary ${ }^{43}$. Natomiast nie da się wyprowadzić z doświadczenia naszego przeświadczenia o istnieniu innych podmiotów i ich relacji, jak również samego przekonania o istnieniu świata zewnętrznego. Volkelt uważa zatem po kantowsku i neokantowsku, że istotną rolę w doświadczeniu odgrywają przyjmowane niezależnie od doświadczenia czynniki aprioryczne. W tym kontekście pisze wręcz o „nędzy doświadczenia”, które nie może dostarczyć podstaw do przekonania o zachodzeniu związku przyczynowego, a także prawidłowości (Gesetzmässigkeit), ciągłości, związku, porządku, jedności czy regularności, ponieważ - zgodnie z pryncypium pozytywistycznym - „moje rzeczywiste procesy świadomości są tym jedynym, czego doświadczam" ${ }^{44}$. Volkelt zatem, tak jak później Wartenberg, wykazuje niedorzeczność pozytywistycznej koncepcji faktów czystego doświadczenia i na przekór pozytywistycznemu scjentyzmowi, który wyklucza metafizykę, dochodzi do wniosku, że „Zasadniczo metafizyka dąży do tego samego, co nauki empiryczne: chce ona uczynić zrozumiałym doświadczenie na podstawie logicznie niezbędnego zamysłu i wyczucia niedoświadczanych czynników"45. Metafizyka postulowana przez Volkelta i pozostałych neokantystów ma być bowiem rodzajem wychodzącej poza doświadczenie ontologii doświadczenia. W tak rozumianej metafizyce „nawet jeżeli nie metafizyczne rozwiązania, to chociaż problemy metafizyczne są formułowane $\mathrm{z}$ biegiem czasu coraz jaśniej i trafniej, alternatywy i rozróżnienia kwestii metafizycznych zostają coraz ostrzej poznane"46. Metafizyczne rozważanie okazuje się zatem celowe choćby ze względu na coraz ściślejszą eksplikację problemów metafizycznych. A to oznacza dla niego, że jeśli można eksplikować określony problem metafizyczny, to również da się w określonym zakresie ściśle ująć rozwiązania danego problemu. Stąd wszelkie metafizyczne twierdzenia metafizyki krytycznej muszą zostać objęte zastrzeżeniem, że uzyskane wnioski są logicznie konieczne, choć wykraczają poza nasze możliwości poznawcze ${ }^{47}$. Tak, nie mają one kategorycznego charakteru sądów apodyktycznych, lecz postulatywny charakter sądów warunkowych. Zawarte w nich przekonania muszą być przedstawione z zastrzeżeniami dotyczącymi ukrytych w nich luk i niejasności, aby zapewnić ich możliwie wszechstronny sprawdzian z róż-

\footnotetext{
43 Por. tamże, s. 22.

${ }_{44}$ Tamże, s. 23.

45 Tamże, s. 26.

46 Tamże, s. 39-40.

47 Por. tamże, s. 28 i nast.
} 
nych punktów widzenia. Chodzi o to, żeby metafizyce nadać naukowy rytm ciągłego niepokoju, poszukiwania i sprawdzania.

Metafizyka Volkelta koresponduje nie tylko z filozofią Kanta, lecz również idealistów niemieckich: Johanna G. Fichtego, Friedricha W. J. von Schellinga, Georga W. F. Hegla, a także z metafizyką Arthura Schopenhauera oraz Eduarda von Hartmanna, Arthura Drewsa, Rudolfa Hermanna Lotzego, jak również neoarystotelizmem Gideona Spickera. Wbrew pozorom Volkelta koncepcja metafizyki krytycznej nie powstała zatem w całkowitej opozycji do wielkich filozofów pokantowskich, takich jak Fichte, Schelling, Hegel czy zwłaszcza Schopenhauer, gdyż istotne elementy metafizyki krytycznej będą zgodne z intuicjami poprzedników ${ }^{48}$. Volkelt pisze:

I tak mogę zatem ostatecznie, do czego dążę, określić jako zjednoczenie i przeniknięcie metafizycznych dążeń idealistycznych, tak jak wypełniali to przede wszystkim niezapomnianie pokantowscy myśliciele, oraz sceptyczno-krytycznego i teoriopoznawczego ducha, tak jak ucieleśniło się to u Hume’a, a szczególnie u subtelnie, a zarazem $\mathrm{z}$ rozmachem pracującego Kanta ${ }^{49}$.

W tym gronie protoplastów Volkelta i Wartenberga nie może oczywiście zabraknąć neokantystów zaliczanych do kierunku metafizycznego, takich jak Otto Liebmann, Friedrich Paulsen, a także Erich Adickes i Traugott Konstantin Österreich. Wszyscy oni postulowali w miejsce starej nową, krytyczną metafizykę jako formę zaspokojenia koniecznej potrzeby umysłu ludzkiego.

\section{Neokantyzm Wartenberga}

\subsection{Wartenberg a Kant}

Trudno zrozumieć filozofię Wartenberga bez odniesień do myśli zawartej w Krytyce czystego rozumu Kanta, która stała się inspiracją dla jego własnego, na wskroś realistycznego światopoglądu. Taka postawa Wartenberga ujawnia się już w jego pracy doktorskiej Kants Theorie der Kausalität mit besonderer Berücksichtigung der Grundprinzipien seiner Theorie der Erfahrung, którą obronił pod kierunkiem wybitnego neokantysty i przedstawiciela kierunku

\footnotetext{
${ }^{48}$ Por. tamże, s. 31.

49 Tamże.
} 
metafizycznego Ottona Liebmanna w Jenie w $1898 \mathrm{roku}^{50}$. Jej przedmiotem jest analiza Kantowskiej teorii przyczynowości. Centralnym zagadnieniem dla Wartenberga staje się jednak kategoria przyczynowości jako warunkujące doświadczenie pojęcie intelektu. Wartenberg krytykuje Kantowski aprioryzm i uznaje, że przyczynowość jest przede wszystkim spontaniczną syntezą, w której świadomość łączy empirycznie dane następstwo zjawisk za pomocą pomyślanego związku przyczynowego ${ }^{51}$. Wartenberg uznaje bowiem, że obiektywną ważność przyczynowości może zapewnić jedynie stały porządek świata transcendentnego wobec świadomości. Stosunek Wartenberga wobec myśli Kanta ujawnia już na początku jego realistyczne nastawienie w filozo$\mathrm{fii}^{52}$. Wartenberg rozumie bowiem poznanie przede wszystkim jako odzwierciedlenie rzeczywistości, co nie było zgodne z Kantowską krytyką teorii odbicia $^{53}$.

O Wartenbergowskim udziale $\mathrm{w}$ dyskusjach kantowskich i neokantowskich świadczy również jego - przyjęta na Uniwersytecie Jagiellońskim - rozprawa habilitacyjna Das Problem des Wirkens und die monistische Weltanschauung mit besonderer Beziehung auf Lotze $(1900)^{54}$, w której obok Lotzego istotne znaczenie dla jego badań uzyskują poglądy - znanego ze słynnej debaty z Kuno Fischerem dotyczącej obiektywności Kantowskich form zmysłowości - Friedricha A. Trendelenburga (1802-1872).

Realistyczne nastawienie Wartenberga ujawnia się również w artykule Kantowska argumentacja przeciw idealizmowi $\mathrm{z} 1905 \mathrm{roku}^{55}$, w którym analizuje sposób argumentacji Kanta, krytykując go za zajęcie stanowiska idealistycznego, przejawiającego się w uznaniu rzeczy samych w sobie za niepoznawalne bez podania racji przemawiającej za ich istnieniem ${ }^{56}$. W jego realistycznej interpretacji myśli Kanta uwidacznia się antyfenomenalistyczne założenie, że idealistyczny charakter Kantowskiej filozofii stanowi skutek niekonsekwencji Kanta wobec rzekomo przyjętych przez niego realistycznych założeń, takich

\footnotetext{
${ }^{50}$ M. Wartenberg, Kants Theorie der Kausalität mit besonderer Berücksichtigung der Grundprinzipien seiner Theorie der Erfahrung, Leipzig 1899.

51 Tamże, s. 213.

${ }^{52}$ M. Kazimierczak, $W$ poszukiwaniu, wyd. cyt., s. 28 i nast.

${ }^{53}$ Por. tamże, s. 82.

${ }^{54}$ Por. M. Wartenberg, Das Problem des Wirkens und die monistische Weltanschauung mit besonderer Beziehung auf Lotze, Leipzig 1900, s. 143.

${ }^{55}$ M. Wartenberg, Kantowska argumentacja przeciw idealizmowi, „Przegląd Filozoficzny” 1905.

${ }^{56}$ Tamże, s. 126.
} 
jak uznanie istnienia rzeczy samych w sobie jako warunku podmiotowego ujęcia zjawiska. W tym kontekście warto nadmienić, że realistyczne stanowisko zajmował również Volkelt, choć jego realizm był inaczej rozumiany.

W 1906 roku ukazał się Wartenbergowski przekład Grundlegung zur Metaphysik der Sitten (Uzasadnienie metafizyki moralności) Kanta, a w 1911 roku tłumaczenie Kritik der praktischen Vernunft (Krytyka praktycznego rozumu) Feliksa Kierskiego, które przejrzał i opatrzył wstępem ${ }^{57}$. Wartenberg przyznaje w nim, że najważniejsze znaczenie Krytyki praktycznego rozumu Kanta polega na stanowczym i konsekwentnym uwolnieniu etyki od eudajmonizmu. Przez tłumaczenia Wartenberg nie tylko propagował myśl etyczną Kanta, lecz również krytycznie odniósł się do jego filozofii praktycznej. Wartenberg uważa bowiem, że Kant - uznając wszystkie naturalne skłonności człowieka za moralnie naganne i zasługujące na odrzucenie - przesadził w swym antyeudajmonizmie i racjonalistycznej obronie czystości zasad. Przyznaje jednak, że Kantowską, na wskroś racjonalistyczną i antynaturalistyczną filozofię praktyczną należy rozumieć jako obronę przeciwko oświeceniowemu sentymentalizmowi i naturalizmowi.

Krytyczną analizę myśli Kanta przedstawia również w rozprawie Zagadnienie czasu z $1916 \mathrm{roku}^{58}$. Wartenberg zarzuca jego koncepcji czasu, że uznaje empiryczną treść zjawisk za nieuformowany i surowy materiał usytuowany poza czasem, tak jak poza przestrzenią. Wartenberg uznaje bowiem niezależną od nas rzeczywistość zmian odbywających się w naszej świadomości za warunek możliwości przedstawienia sobie następstwa w czasie poza nami ${ }^{59}$. Punktem odniesienia dla Wartenberga jest jednak z jednej strony podmiot empiryczny, a nie transcendentalny, tak jak u Kanta, a z drugiej - istniejąca niezależnie od podmiotu rzeczywistość. Ostatecznie dochodzi do wniosku, że czas - tak jak cała natura rzeczywistości - jest czymś niepojętym i tajemniczym, zbliżając się tym samym do stanowiska Kantowskiego krytycyzmu.

Wartenberg w swej filozofii koresponduje jednak nie tylko z myślą Kanta, lecz również z jego innymi duchowymi spadkobiercami. Marek Kazimierczak dostrzega zbieżność z realistycznie zabarwioną metafizyką J. F. Herbarta (1776-1841) i A. Schopenhauera (1788-1860) oraz przede wszystkim z prekursorami metafizyki indukcyjnej, takimi jak Jacob Fries (1773-1843),

\footnotetext{
${ }^{57}$ Por. I. Kant, Uzasadnienie metafizyki moralności, przeł. M. Wartenberg, Lwów 1906; I. Kant, Krytyka praktycznego rozumu, przeł. F. Kierski, Lwów 1911.

${ }_{58}^{58}$ M. Wartenberg, Zagadnienie czasu, Lwów 1916, s. 555.

59 Tamże, s. 567.
} 
Friedrich Beneke (1798-1854), Gustaw Teodor Fechner (1802-1887), Rudolf Hermann Lotze (1817-1881), Eduard von Hartmann (1842-1906) czy Wilhelm Wundt (1832-1920), a także przedstawiciele tzw. wczesnej fazy neokantyzmu - Friedrich Albert Lange (1828-1875) i Otto Liebmann (1842$1912)^{60}$. Wszyscy oni krytykowali spekulatywny idealizm oraz materializm i jednocześnie postulowali metafizykę jako formę zaspokojenia koniecznej potrzeby umysłu ludzkiego.

\subsection{Wartenberga obrona metafizyki}

Istotne dla naszych rozważań jest Wartenbergowskie nawiązanie do nurtu metafizyki indukcyjnej, który postuluje, że nie treść systemu, lecz metoda badań może zapewnić naukowość metafizyki ${ }^{61}$. W pierwszej kolejności Wartenberg odnosi się do poglądów Lotzego na temat wzajemnego oddziaływania pomiędzy substancją materialną a substancją duchową. Wartenberg krytykuje Lotzego za redukcję wszystkich pojedynczych bytów do jednej, absolutnej i substancjalnej podstawy świata, ale jednocześnie zgadza się, że jednostkom przysługuje tylko względna samoistność bytowa. Z transcendentnym realizmem E. von Hartmanna zgadza się w kwestii istnienia niezależnych od nas i dynamicznie oddziałujących atomów. Za W. Wundtem przyjmuje metodę indukcyjną w metafizyce i uznaje, że metafizyka, mówiąc o substancji, materii i duszy, musi być hipotetyczna, gdyż każda hipoteza, o ile nie jest tylko przypuszczeniem o faktach, które mogą być empirycznie dowiedzione, jest metafizyczna. Wartenberg ma jednak krytyczny stosunek do koncepcji psychofizycznego paralelizmu W. Wundta i sprzeciwia się takiej próbie eliminowania przyczynowego stosunku pomiędzy ciałem i duszą.

Wartenberga łączy ze zwolennikami metafizyki indukcyjnej przekonanie o teoretycznej i praktycznej potrzebie oraz możliwości istnienia metafizyki jako nauki. Analizę i odparcie zarzutów przeciwko możliwości naukowego uprawiania metafizyki Wartenberg podejmuje w rozprawie Obrona metafizyki z 1902 roku. Przeciwstawia się zarówno pozytywistycznej próbie kwestionowania przedmiotowej odrębności metafizyki (R. Avenarius, E. Mach, H. Spencer), jak też neokantowskim próbom kwestionowania możliwości jej naukowego uprawiania (F. A. Lange, O. Liebmann). Wartenberg uważa, że wobec przyjęcia przez nauki szczegółowe szeregu metafizycznych pojęć,

\footnotetext{
${ }^{60}$ Por. M. Kazimierczak, W poszukiwaniu, wyd. cyt., s. 58 i nast.

${ }^{61}$ Por. tamże, s. 59 i nast.
} 
takich jak materia, czas, przestrzeń, ruch, zmiana i inne, musi istnieć taka dyscyplina naukowa, czyli metafizyka, która dokona ich krytycznej analizy.

Wartenberg wykazuje niedorzeczność pozytywizmu, który postuluje oparcie nauki na tzw. czystym doświadczeniu faktów, stwierdzając, że oznacza to rezygnację z koniecznych $\mathrm{w}$ doświadczeniu form poznawczych (kategorii), takich jak stosunek rzeczy do jej własności czy związek przyczynowo-skutkowy. Choć kategorie należą do wewnętrznej organizacji umysłu, to stanowią konieczne formy pojmowania przedmiotów ${ }^{62}$. Wartenberg, nie negując roli faktów w poznaniu, podkreśla znaczenie nieempirycznych hipotez, które odpowiadają faktom i przyczyniają się do ich wytłumaczenia.

Szczególnie istotne jest przekonanie Wartenberga o bezpodstawności tezy pozytywistów, że brak miejsca na badania metafizyczne nad rzeczywistością, ponieważ całość rzeczywistości została podzielona między nauki szczegółowe. Wartenberg uważa, że metafizyka może kontynuować badania rozpoczęte przez nauki szczegółowe przez krytyczną analizę pojęć, by określić istotę zjawisk i ostatecznie wypracować naukowy pogląd na świat ${ }^{63}$. W naukowym poglądzie na świat powinny znaleźć się rozwiązania zasadniczych kwestii metafizyki, między innymi takich, jak problem duszy i ciała, problem monizmu lub problem panteizmu.

Podobnie jak Volket, Wartenberg z dystansem odnosił się nie tylko do pozytywizmu, lecz również do neokantyzmu („nowokantyzmu”), ze względu na jego stosunek do metafizyki. Dzielił "nowokantystów” na skrajnych, takich jak Friedrich A. Lange, oraz umiarkowanych - jak Otto Liebmann ${ }^{64}$. W szczególności odrzucał użyte przez Langego określenie metafizyki jako pozbawionej naukowego charakteru „poezji myślowej”. Takiej „poetyckiej” i tym samym nienaukowej metafizyce przeciwstawiał własne rozumienie metafizyki jako nauki teoretycznej.

Inaczej odnosił się Wartenberg do - promotora swej pracy doktorskiej Liebmanna, który nie zaprzeczał możliwości naukowego uprawiania metafizyki i w duchu Kanta chciał łączyć empiryzm (fenomenalizm) z metafizycz-

${ }^{62}$ Por. M. Wartenberg, Obrona metafizyki. Krytyczny wstep do metafizyki, Kraków 1902, s. 70.

${ }^{63}$ Por. tamże, s. 46.

${ }^{64}$ Por. M. Kazimierczak, W poszukiwaniu, wyd. cyt., s. 75. Tak jak w przypadku Volkelta dystans Wartenberga wobec formacji neokantowskiej nie wyklucza możliwości zakwalifikowania go pod względem historycznofilozoficznym do tego nurtu filozoficznego. Zdecydowana większość filozofów zaliczanych do neokantyzmu wcale nie identyfikowała się z tym nurtem i niejednokrotnie zajmowała krytyczne stanowisko wobec filozofii neokantowskiej, co należy traktować jako jedną z cech charakterystycznych tej formacji. 
nym racjonalizmem. W odniesieniu do problemu metafizyki Liebmann, tak jak Wartenberg i Volkelt, w duchu neokantowskiego agnostycyzmu dopuszczali metafizykę nie jako naukę formułującą apodyktyczne twierdzenia, lecz wyrażającą hipotetyczne przypuszczenia. Mimo dzielących ich różnic w sposobie rozumienia metafizyki i jej możliwości jako nauki Liebmannowski postulat metafizyki krytycznej pozostającej w ścisłym związku z rezultatami badań nauk szczegółowych, a zwłaszcza opartej na doświadczeniu bardziej łączył, niż różnił stanowiska obu myślicieli. Uwidacznia się to w szczególności w tezie o istnieniu paralelnej interakcji między podmiotowymi wyobrażeniami a rzeczywistością świata realnego.

Wartenberga i Liebmanna łączy również teoriopoznawcze przekonanie o pośrednim charakterze poznania, w którym istotną rolę odgrywają „czynniki pozaempiryczne”. Liebmann nazywa je "maksymami interpolacyjnymi doświadczenia" i wśród nich wymienia zasady takie, jak zasada realnej tożsamości, zasada ciągłości bytu, zasada przyczynowości, zasada ciągłości stawania $\operatorname{sie}^{65}$. Natomiast Wartenberg również po Kantowsku przyjmuje, że podstawą doświadczenia jest samodzielna i syntetyczna czynność umysłu, uwarunkowana przez jedność i tożsamość świadomości. Różnice między nimi dotyczą sposobu rozumienia podmiotu poznania doświadczalnego. Można zatem powiedzieć, że stanowisko Wartenberga w kwestii możliwości metafizyki jako nauki nie różni się zbyt mocno od poglądów ówczesnych zwolenników metafizyki indukcyjnej (Hermann Lotze, Eduard von Hartmann czy Wilhelm Wundt). Podobnie jak oni, w tak rozumianej metafizyce dostrzega jakąś formę kontynuacji i syntezy nauk szczegółowych. Tak jak dla pozostałych wymienionych myślicieli, nauki szczegółowe stanowiły dla Wartenberga konieczny warunek możliwości metafizyki, który zapewnia jej oparcie na faktach czerpanych $\mathrm{z}$ doświadczenia $\mathrm{w}$ celu wyjścia poza doświadczenie.

\section{Uwagi końcowe}

Jeśli polska recepcja filozofii Kanta miała być - tak jak uważam - przyjęciem ducha tej filozofii, to musi być $\mathrm{z}$ istoty neokantyzmem, który nigdy nie polegał na wierności literze, lecz na wyjściu poza myśl filozofa z Królewca. Widać to wyraźnie na przedstawionym w niniejszej pracy przykładzie po-

\footnotetext{
${ }^{65}$ Por. O. Liebmann, Die Klimax der Theorie, Strassburg 1884, s. 107.
} 
glądów filozoficznych Wartenberga i Volkelta, w których można wyróżnić zarówno etap wykładni myśli Kanta, jak też ich konsekwentnego rozwinięcia. Wartenberg w swej interpretacji, tak jak neokantyści, nie stawia pytania, co w istocie Kant miał na myśli, lecz przede wszystkim pyta, czy miał rację w swych przekonaniach. Tak jak w neokantyzmie poglądy Kanta stały się dla niego punktem krytycznego odniesienia. Podobnie sytuacja wygląda w rozwoju filozoficznym Volkelta.

Przeprowadzone porównanie wykazało daleko idącą zbieżność poglądów Wartenberga i Volkelta nie tylko w kwestii odczytania myśli Kanta, lecz również ich wniosków dotyczących problemu metafizyki. Obaj dostrzegają tkwiącą w naturze człowieka metafizyczną potrzebę i postulują możliwość uprawiania otwartej na wyzwania stawiane przez naukę metafizyki, a tym samym ich poglądy sytuują się w nurcie poheglowskiej metafizyki krytycznej, czyli tak zwanej metafizyki indukcyjnej. Obaj stoją na stanowisku realistycznym, choć widoczne są pewne różnice dotyczące sposobu, w jaki realizmu ten rozumieją. Różnice te ujawniają się na poziomie argumentacji, w której Wartenberg - inaczej niż Volkelt - wyraźnie odwołuje się do teorii odbicia. W sposobie uzasadnienia poglądów Volkelt pozostaje pod wyraźnym wpływem myśli Heglowskiej i idealizmu niemieckiego, podczas gdy Wartenberg wydaje się wolny od tych wpływów.

\section{Bibliografia}

Hallesby O., Johannes Volkelts Erkenntnistheorie. Eine Darstellung und Kritik, Dissertation, Erlangen 1909.

Kant I., Krytyka czystego rozumu, przeł. M. Żelazny, [w:] I. Kant, Dzieła zebrane, t. 2, red. M. A. Chojnacka, M. Marciniak, Torun 2013.

Kant I., Krytyka praktycznego rozumu, przeł. F. Kierski, Lwów 1911.

Kant I., Uzasadnienie metafizyki moralności, przeł. M. Wartenberg, Lwów 1906.

Kazimierczak M., W poszukiwaniu naukowego charakteru metafizyki. Z dziejów recepcji niemieckiej filozofii pokantowskiej w Polsce, Poznań 1998.

Kubalica T., Johannes Volkelt a problem metafizyki, „Estetyka i Krytyka” 2012, t. 26, s. 27-49.

Kubalica T., Metafizyka krytyczna Otto Liebmanna, „Folia philosophica” 2014, t. 31.

Kubalica T., Problem pewności w neokantyzmie Johannesa Volkelta, „Folia philosophica" 2013, t. 31, s. 133-156.

Liebmann O., Die Klimax der Theorie, Strassburg 1884.

Neumann T., Gewissheit und Skepsis. Untersuchungen zur Philosophie Johannes Volkelts, Amsterdam 1978. 
Noras A. J., Historia neokantyzmu, Katowice 2012.

Noras A. J., Kant a neokantyzm badeński i marburski, Katowice 2000.

Volkelt J., Die Aufgabe und die Fundamental schwierigkeit der Erkenntnistheorie als einer voraussetzungslosen Wissenschaft, "PhilosophischeMonatshefte” 1881, t. 17, s. 513-541.

Volkelt J., Die Gefühlsgewissheit. Eine erkenntnistheoretische Untersuchung, München 1922 (fragmenty w: J. Volkelt, Pewność uczuciowa. Wybór tekstów, przeł. B. Markiewicz. Warszawa 1983).

Volkelt J., Erfahrung und Denken. Kritische Grundlegung der Erkenntnistheorie, Hildesheim 2002.

Volkelt J., Immanuel Kant's Erkenntnistheorie: nach ihren Grundprincipien analysirt: ein Beitrag zur Grundlegung der Erkenntnistheorie, Leipzig 1879.

Volkelt J., Über die Möglichkeit der Metaphysik: Antrittsrede gehalten zu Baselam 23. Oktober 1883, Hamburg 1884.

Volkelt J., Vorträge zur Einführung in die Philosophie der Gegenwart, München 1892.

Wartenberg M., Das Problem des Wirkens und die monistische Weltanschauung mit besonderer Beziehung auf Lotze, Leipzig 1900.

Wartenberg M., Kantowska argumentacja przeciw idealizmowi, „Przegląd Filozoficzny" 1905.

Wartenberg M., Kants Theorie der Kausalität mit besonderer Berücksichtigung der Grundprinzipiens einer Theorie der Erfahrung, Leipzig 1899.

Wartenberg M., Obrona metafizyki. Krytyczny wstęp do metafizyki, Kraków 1902.

Wartenberg M., Zagadnienie czasu, Lwów 1916.

\section{Abstract \\ Johannes Volkelt and Mścisław Wartenberg - Neo-Kantian Philosophy of Kant in Poland}

The paper is devoted to an issue of Polish reception of Kant's thought and an history of Polish research on this philosophy. It concerns the impact of NeoKantianism to assimilate the ideas of Kant in Poland. Its subjectis the comparison of the philosophical ideas of the twothinkers in different ways related to Polish: Johannes Volkelt (1848-1930) from Lipnik (now part of Bielsko-Biała) and professor of philosophy at the Jan Kazimierz University of Lviv Mścisław Wartenberg (1868-1938). Philosophically connect their research on the thought of Kant and the defense of the scientific nature of metaphysics. The purpose of this comparison is to identify the border between the literal reading of Kant's philosophy and the spirit expressed in a new way by the Neo-Kantians.

Key words: J. Volkelt, M. Wartemberg, Neo-Kantianism, Polish philosophy, German philosophy, history of philosophy 